\title{
SEED GERMINATION \\ IN ARCTIC AND ALPINE SPECIES
}

\author{
L. C. Bliss*
}

\begin{abstract}
A
RCTIC and alpine species today occupy large areas that only a few thousand years ago were covered by great ice sheets or the sea. Not all arctic land areas were glaciated, however, for refugia such as Beringia, the coast of northern Alaska, the Yukon valley, and a part of the Arctic Archipelago remained free of ice and there many species were able to survive, rather than suffer extinction or be forced by the advancing ice to migrate south (Hultén, 1937). Although the numbers of biotypes (or strains) of many species were reduced and thus the adaptability of these species impaired by the considerable climatic changes caused by the alternation of warm and dry interglacial and cold glacial periods, many retained the capacity to recolonize their former habitats after the ice had finally retreated. This recolonization is the result of both vegetative reproduction by bulblets, runners, rhizomes, etc., and dispersal by seeds.

The present study was undertaken to give a better understanding of seed viability of both arctic and alpine species; for field observations indicate that seedlings are not numerous, especially in the Arctic. Nomenclature follows that of Hultén (1941-50) for the arctic species and Harrington (1954) for the alpine species. Appreciative acknowledgement is made to the Department of Botany, Duke University, where the germination tests were made and to Boston Physical Research Laboratories under the auspices of which the Alaskan work was carried out.

An extensive study of flower development and seed germination of arctic-alpine species has been made by Söyrinki (1938-9) in PetsamoLappland. Of 91 species tested 79 germinated. Sørensen (1941) ran germination tests on the seeds of 99 species in northeast Greenland, in which those of 62 species germinated. Nearly one half of those that failed to germinate belonged to the Cyperaceae (sedge family). He found that germination occurred even though the seeds remained frozen for almost half of each 24-hour period. Seed production by arctic and alpine species has been discussed by A. E. Porsild (1920), M. P. Porsild (1920), Holttum (1922), and Böcher (1949); and seed dispersal mechanisms by Holm (1922) and Porsild (1951). Growth rates and survival of seedlings in Greenland were studied by Wager (1938). Stoeckeler (1949) reported that arctic willow seeds require a mineral substrate for germination, whereas seeds of alder and birch germinate on peat.
\end{abstract}

* Department of Botany, University of Illinois, Urbana, Ill. 
Nichols (1934) ran germination tests on seeds of 19 alpine species from the White Mountains, New Hampshire. These showed that without refrigeration germination was considerably reduced in 14 of the 19 species. Pelton (1956) found that of 18 species from Colorado, collected in the subalpine zone, alpine bistort (Polygonum viviparum) and trisetum (Trisetum spicatum) seeds did not require dormancy. Holch et al. (1941) reported that rhizomes provide the best means of propagation of alpine plants in the Rocky Mountain Park. They stated (p. 339) ". . . the short growing season results either in the production of no seed or of small amounts of seed of low vitality."

The germination studies reported here were made on 36 arctic and 26 alpine species. Seeds of the arctic species were collected directly from plants in and near Umiat, Alaska, $69^{\circ} 22^{\prime} \mathrm{N}$. $152^{\circ} 10^{\prime} \mathrm{W}$., 350 feet above sealevel, in August 1953. Northern Alaska, including Umiat, is designated as "low arctic" by Polunin (1951) in contrast to the climatically more severe and floristically poor "high arctic" farther north. This low arctic region is characterized by extensive sedge marshes, lichen-rich heaths, and shrub communities 1 metre or more in height in sheltered places. Some of the arctic species reported here range from boreal to low arctic regions, whereas others range from low to high arctic regions. The species are so marked in Table 1. Seeds of the alpine species were obtained from plants growing in the alpine tundra of the Snowy Range of the Medicine Bow Mountains, $41^{\circ} 20^{\prime} \mathrm{N}$. $106^{\circ} 19^{\prime} \mathrm{W} ., 11,000$ feet above sea-level, approximately 40 miles west of Laramie, Wyoming, in 1954 and 1955. Seeds were placed in glass vials or paper bags, air dried and shipped to Duke University, where they were stored at $5^{\circ} \mathrm{F}$. for 6 to 7 months. After removal from storage, the seeds were cleaned, sorted and the unfilled and shrunken ones removed. Seeds from fleshy fruits were separated before testing. Duplicate samples of untreated seeds were placed in sterilized Petri dishes between layers of moist filter paper and incubated at $72^{\circ} \mathrm{F}$., one sample in the light and the other in the dark. Distilled water was added when necessary to keep the filter paper moist. The dishes were removed twice a week for seed counting, at which time the continuous dark period was broken for approximately 1 hour. The number of seeds tested varied according to the quantity of seed available. Seeds were considered to have germinated when the radicle appeared.

The data in Table 1 show that of the 36 arctic species only 22 species or 61 per cent and of the 26 alpine species 21 or 80 per cent germinated. Arctic species that did not germinate included 5 ericaceous species, 3 each of willow (Salix) and lousewort (Pedicularis), also buckbean (Menyanthes trifoliata), Lapland buttercup (Ranunculus lapponicus), and cloudberry (Rubus chamaemorus). Alpine species not germinating included 2 species of willow (Salix) and 3 of sedge (Carex).

No great differences were found between the average germination percentages of the various species from the two tundras. Thus 13 of the 22 arctic species and 10 of the 21 alpine species germinated at the 50 per cent level or better. Eleven of the 22 arctic species that germinated in the light 
showed a significant change ${ }^{1}$ in germination percentage when kept dark; 10 species showed a reduction and 1 an increase in percentage. Only 6 of the 21 alpine species that germinated in the light were significantly affected by continuous darkness; germination percentages were reduced in 5 and increased in 1 species. None of the arctic or alpine species germinated exclusively in the dark, but 9 of the 43 did so only in the light.

All arctic species tested that were usually found growing on deeply thawed soil, with the exception of feltleaf willow (Salix alaxensis), germinated in both light and darkness, in contrast to those arctic species that

Table 1. Germination percentages for arctic and alpine species. The data include minimum, mean, and maximum germination time in days. Range of the arctic species is shown as follows: $\mathrm{B}=$ boreal, $\mathrm{LA}=$ low arctic, $\mathrm{HA}=$ high arctic.

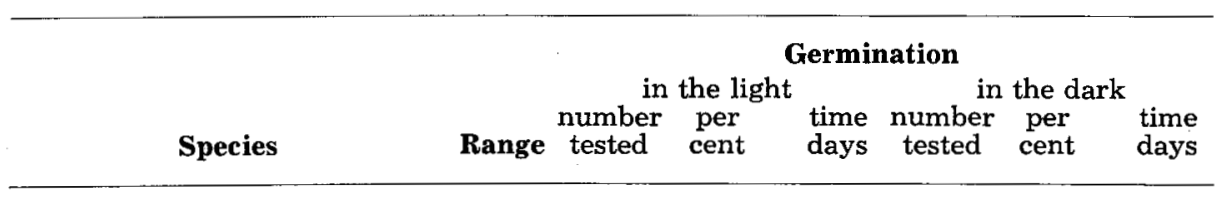

Arctic species

Common on deeply thawed soils

Erigeron purpuratus Crepis nana

Epilobium latifolium Parnassia palustris

Lupinus arcticus

Aster sibiricus

Astragalus alpinus

Papaver radicatum

Senecio congestus

Oxytropis sp.

Salix alaxensis

Petasites frigidus

Arctagrostis latifolia

Dryas integrifolia

Cassiope tetragona

Betula nana exilis

Ledum palustre decumbens

Saxifraga punctata nelsoniana

Eriophorum vaginatum spissum

Alnus crispa

Carex bigelowii

Carex aquatilis

Eriophorum angustifolium

Andromeda polifolia

Arctostaphylos alpina

Empetrum nigrum

Menyanthes trifoliata

Pedicularis capitata

Pedicularis labradorica

Pedicularis lanata

Ranunculus lapponicus

Rubus chamaemorus

Salix arbusculoides

Salix pulchra

Vaccinium uliginosum

Vaccinium vitis-idaea minus

$\begin{array}{lr}\text { LA } & 47 \\ \text { B-HA } & 114 \\ \text { B-HA } & 72 \\ \text { B-LA } & 109 \\ \text { B-LA } & 79 \\ \text { B-LA } & 32 \\ \text { B-HA } & 86 \\ \text { LA-HA } & \mathbf{1 0 5 4} \\ \text { B-HA } & 136 \\ \text { B-LA } & 39 \\ \text { B-LA } & 154\end{array}$

$\begin{array}{rr}\mathbf{1 0 0 . 0} & 4-4-11 \\ \mathbf{9 7 . 4} & \mathbf{3}-\mathbf{3}-\mathbf{6} \\ \mathbf{9 4 . 5} & \mathbf{7 - 7 - 1 1} \\ \mathbf{8 6 . 0} & 7-7-10 \\ \mathbf{7 5 . 1} & \mathbf{6 - 1 0 - 1 9} \\ \mathbf{5 6 . 3} & 4-11-21 \\ \mathbf{3 9 . 5} & 4-7-19 \\ \mathbf{2 3 . 0} & \mathbf{7 - 1 0 - 2 4} \\ \mathbf{2 1 . 0} & 3-3-7 \\ 18.0 & 4-7-7 \\ 0.0 & 0-0-0\end{array}$

$\begin{array}{rcc}\mathbf{7 2} & \mathbf{1 0 0 . 0} & \mathbf{4}-6-11 \\ \mathbf{6 5} & \mathbf{9 8 . 5} & \mathbf{3}-\mathbf{3}-10 \\ \mathbf{5 5} & \mathbf{9 1 . 0} & \mathbf{3}-\mathbf{7 - 1 1} \\ \mathbf{1 8 8} & \mathbf{8 5 . 2} & \mathbf{7}-\mathbf{7 - 1 0} \\ \mathbf{5 9} & \mathbf{6 3 . 4} & \mathbf{3}-3-14 \\ \mathbf{5 8} & \mathbf{5 0 . 0} & \mathbf{4}-\mathbf{7 - 2 1} \\ \mathbf{3 4} & \mathbf{5 9 . 0 \dagger} & \mathbf{4}-\mathbf{7 - 1 9} \\ \mathbf{4 5 4} & \mathbf{5 . 4} & \mathbf{7}-\mathbf{7}-14 \\ \mathbf{1 3 2} & \mathbf{4 . 5 *} & \mathbf{3}-\mathbf{3}-\mathbf{3} \\ \mathbf{3 9} & 18.0 & 4-\mathbf{7}-14 \\ 120 & 0.0 & 0-0-0\end{array}$

Common on shallowly thawed soils

\begin{tabular}{|c|c|c|c|c|c|c|}
\hline $\begin{array}{l}\text { B-HA } \\
\text { B-HA } \\
\text { B-HA } \\
\text { LA-HA } \\
\text { LA } \\
\text { B-LA } \\
\text { B-LA } \\
\text { B-LA } \\
\text { B-LA } \\
\text { B-HA } \\
\text { B-HA } \\
\text { B-LA } \\
\text { B-LA } \\
\text { B-LA } \\
\text { B-HA } \\
\text { B-LA } \\
\text { B-HA } \\
\text { B-LA } \\
\text { B-HA } \\
\text { B-LA } \\
\text { B-LA } \\
\text { B-LA } \\
\text { B-LA } \\
\text { B-HA } \\
\text { B-LA }\end{array}$ & $\begin{array}{r}80 \\
44 \\
52 \\
293 \\
54 \\
1273 \\
283 \\
479 \\
100 \\
288 \\
147 \\
338 \\
90 \\
39 \\
67 \\
63 \\
74 \\
\mathbf{5 7} \\
58 \\
135 \\
50 \\
116 \\
140 \\
98 \\
136\end{array}$ & $\begin{array}{r}96.0 \\
80.0 \\
67.0 \\
52.0 \\
52.0 \\
51.2 \\
37.5 \\
22.6 \\
15.0 \\
6.2 \\
2.7 \\
0.9 \\
0.0 \\
0.0 \\
0.0 \\
0.0 \\
0.0 \\
0.0 \\
0.0 \\
0.0 \\
0.0 \\
0.0 \\
0.0 \\
0.0 \\
0.0\end{array}$ & $\begin{array}{r}3-3-14 \\
7-14-21 \\
7-7-35 \\
7-21-26 \\
3-3-13 \\
10-13-25 \\
6-17-25 \\
7-10-35 \\
3-6-13 \\
10-10-10 \\
6-6-10 \\
3-3-10 \\
0-0-0 \\
0-0-0 \\
0-0-0 \\
0-0-0 \\
0-0-0 \\
0-0-0 \\
0-0-0 \\
0-0-0 \\
0-0-0 \\
0-0-0 \\
0-0-0 \\
0-0-0 \\
0-0-0\end{array}$ & $\begin{array}{r}84 \\
42 \\
36 \\
177 \\
43 \\
531 \\
297 \\
286 \\
66 \\
149 \\
94 \\
332 \\
62 \\
30 \\
61 \\
49 \\
73 \\
52 \\
77 \\
138 \\
57 \\
104 \\
110 \\
102 \\
112\end{array}$ & $\begin{array}{c}87.0^{\dagger} \\
9.6^{*} \\
81.0^{*} \\
0.0^{*} \\
38.2 \\
0.0^{*} \\
0.0^{*} \\
0.0^{*} \\
2.3^{*} \\
0.0^{\dagger} \\
0.0^{\circ} \\
1.2 \\
0.0 \\
0.0 \\
0.0 \\
0.0 \\
0.0 \\
0.0 \\
0.0 \\
0.0 \\
0.0 \\
0.0 \\
0.0 \\
0.0 \\
0.0\end{array}$ & $\begin{array}{r}3-7-21 \\
7-14-21 \\
10-14-28 \\
0-0-0 \\
6-6-17 \\
0-0-0 \\
0-0-0 \\
0-0-0 \\
17-17-17 \\
0-0-0 \\
0-0-0 \\
10-10-17 \\
0-0-0 \\
0-0-0 \\
0-0-0 \\
0-0-0 \\
0-0-0 \\
0-0-0 \\
0-0-0 \\
0-0-0 \\
0-0-0 \\
0-0-0 \\
0-0-0 \\
0-0-0 \\
0-0-0\end{array}$ \\
\hline
\end{tabular}

1 Statistical analysis based on the standard error of the difference test. 
Androsace septentrionalis

Hymenoxys grandiflora

Artemisia scopulorum

Arenaria obtusiloba

Geum turbinatum

Erigeron pinnatisectus

Silene acaulis

Phleum alpinum

Poa alpina

Trisetum spicatum

Sibbaldia procumbens

Trifolium dasyphyllum

Salix brachycarpa

Kalmia polifolia microphylla

Oxytropis campestris glabrata

Polygonum bistortoides

Draba crassifolia

Potentilla diversifolia

Polygonum viviparum

Polemonium viscosum

Pedicularis parryi

Carex aquatilis

Carex drummondiana

Carex scopulorum

Salix cascadensis

Salix planifolia monica

\section{Alpine species}

\begin{tabular}{|c|c|c|c|c|c|}
\hline 35 & 100.0 & $5-8-8$ & 37 & 100.0 & $5-5$ \\
\hline 149 & 100.0 & $5-5-19$ & 185 & 98.0 & 2 \\
\hline 22 & 100.0 & $5-12-12$ & 24 & 92.0 & -19 \\
\hline 24 & 100.0 & $5-12$ & 27 & 85.0 & 5-1 \\
\hline 38 & 100.0 & $5-29$ & 41 & $78.0 *$ & $12-$ \\
\hline 128 & 98.0 & $5-15$ & 132 & 96.5 & $5-1$ \\
\hline 239 & 86.7 & $5-26$ & 191 & 89.7 & $5-26$ \\
\hline 14 & 86.6 & $8-15-40$ & 92 & $76.0 \dagger$ & $12-3$ \\
\hline 11 & 85.5 & $8-22$ & 68 & 91.2 & 8 \\
\hline 46 & 54. & $8-12-40$ & 39 & $77.1 \dagger$ & \\
\hline 76 & 44.0 & 8-19 & 44 & 43.3 & \\
\hline 35 & 37.1 & $5-40$ & 41 & 46.4 & \\
\hline 127 & 27.5 & $7-11-25$ & 109 & 23.0 & $7-11-2$ \\
\hline 73 & 24.6 & $12-22-40$ & 90 & $0.0^{*}$ & $-0-0$ \\
\hline 8 & 21.2 & $4-4-25$ & 148 & 22.3 & $4-11-32$ \\
\hline 7 & 19.2 & $14-18-32$ & 92 & $3.2^{*}$ & $11-21-2$ \\
\hline 8 & 11.1 & $8-8-26$ & 65 & $0.0 \dagger$ & -0 \\
\hline & 10.5 & $12-12-12$ & 2 & 8.3 & \\
\hline 76 & 4.0 & 14-14-18 & 127 & 9.5 & \\
\hline 109 & 2.8 & $-8-8$ & 88 & 0.0 & \\
\hline 8 & 1.2 & & 114 & 2.9 & \\
\hline 4 & 0. & -0 & 52 & 0.0 & -0 \\
\hline & 0 & 0 & 41 & 0.0 & \\
\hline & 0.0 & 0 & 67 & 0.0 & \\
\hline & 0 . & & 8 & 0.0 & \\
\hline & 0. & & 80 & 0.0 & \\
\hline
\end{tabular}

$\dagger$ Significant difference at the $\mathbf{5}$ per cent level.

* Significant difference at the 1 per cent level.

most frequently occurred on the wet tundra soils that thawed only shallowly. Only 48 per cent of the last group germinated under both conditions; some with only very low percentages.

Among the arctic species, white heather (Cassiope tetragona) and Labrador tea (Ledum palustre ssp. decumbens) had 50 per cent germination in the light and no germination in the dark. Germination of the grass Arctagrostis latifolia and the saxifrage Saxifraga punctata ssp. nelsoniana was reduced in the dark by 70 and 37.5 per cent respectively. Cotton-grass (Eriophorum vaginatum ssp. spissum) seeds did not germinate in the dark, yet when the same seeds were placed in constant illumination 22 per cent of them germinated, which was about the same percentage as that for the seeds placed into the light immediately (23 per cent). This species was the only one to show this behaviour.

The alpine species in which germination in the dark was reduced by at least 20 per cent included an avens (Geum turbinatum) and bog laurel (Kalmia polifolia ssp. microphylla); in contrast germination in Trisetum spicatum increased by 23 per cent in the dark. Seeds of most alpine species showed no significant reduction of germination in continuous darkness.

Many seedlings of the willow Salix planifolia var. monica were found in the field in late July after seed dispersal. Since seeds failed to germinate after 7 months of storage, field germination tests were made to determine the duration of seed viability. Freshly collected, air-dried seeds were used in 1955 and between 500 and 1,000 were tested each week. The results show that germination was at first very high (94 per cent), but it had dropped 


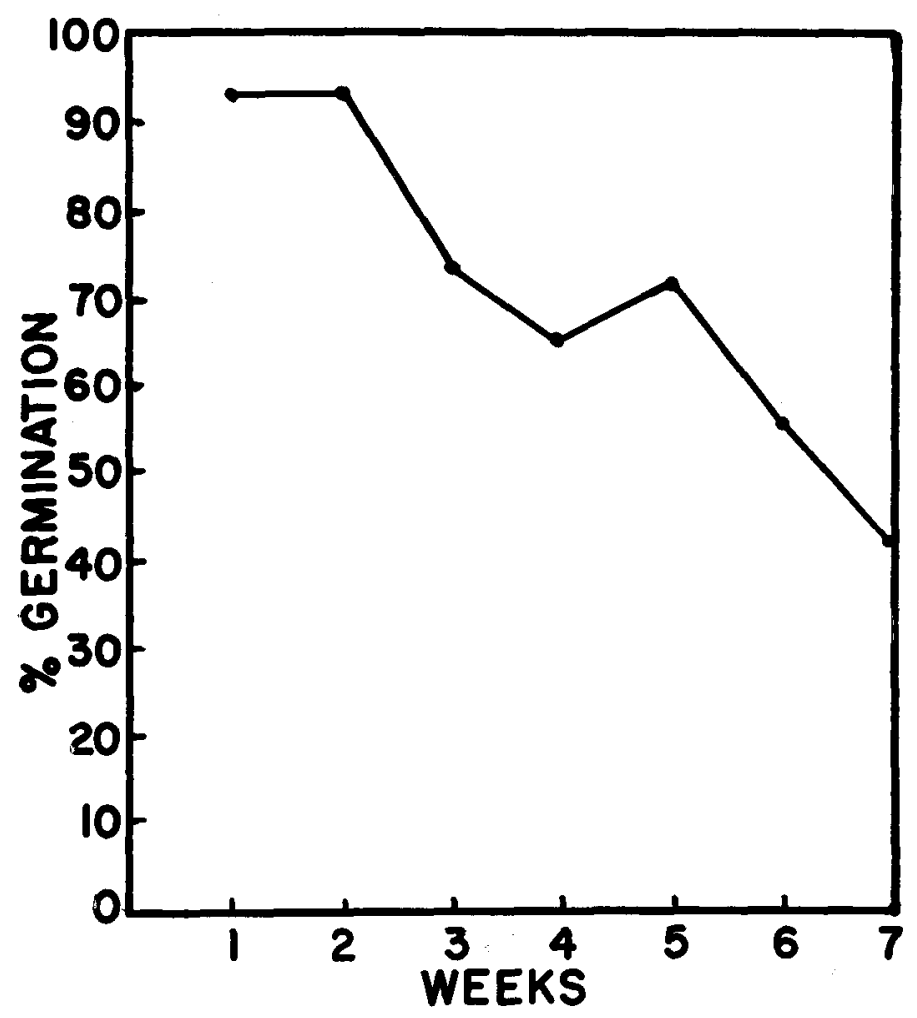

Fig. 1. Seed germination for the alpine willow (Salix planifolia var. monica). Seed was collected in July 1955 and tested immediately.

to 42 per cent by the seventh week (Fig. 1). These seeds were subjected to daily temperature fluctuations and alternating day and night in the mountains.

Although all data presented in Table 1 are the results of germination tests carried out with seeds that had been frozen for from 6 to 7 months, a few of the arctic seeds germinated after having been stored for 30 months. Of those tested after this period of storage, alder (Alnus crispa), birch (Betula nana ssp. exilis), cotton-grass (Eriophorum vaginatum ssp. spissum), and sedge (Carex aquatilis) had germination percentages that were comparable to those reported above. How long these seeds will remain viable is not yet known.

A small percentage of the seeds of Carex aquatilis collected in Alaska germinated, but none from the alpine tundra. Although no data are included for arctic seeds of Polygonum viviparum and Trisetum spicatum, seeds of these two species were collected and tested at a later date. The results showed that both produce viable seed in the two tundras, but germination percentages for both were somewhat higher for the arctic than for the alpine seeds. 
The failure of the seed of some species to germinate should not be interpreted as an indication of non-viability, because the conditions essential for germination may not have been provided. These could be in the form of lower temperatures, alternating temperatures, differences in photoperiod, or scarification.

The data of Table 1 suggest that the arctic species are divided into two habitat groups according to whether the germination of their seeds is significantly reduced in the dark or not, i.e., those species of which the seeds germinate equally well in the light and in the dark grow commonly on the deeply thawed soils of river bottoms, flood plains, steep slopes, dry ridge tops, and the raised rims of polygons; whereas those species in which the seeds do not germinate in the dark or only in small proportions grow generally in upland, wet tundra soils that thaw only shallowly. The former (non-light-sensitive) germination pattern is also typical of the alpine species tested.

Ecologically these reactions to light and dark treatment can be explained in several ways. The arctic species with seeds that germinate equally well in light and darkness frequently grow where the seeds are subject to burial by spring flooding with the resultant accumulation of sand and silt (Bliss and Cantlon, 1957), as opposed to the light-sensitive species usually found in upland tundra areas, the seeds of which become rarely buried because of the slow rate of accumulation of organic matter. On the other hand, burial of seeds of both arctic and alpine species could result from wind-blown sand or silt.

Another possibility is that the significantly higher germination in the light in the species common to wet, shallowly thawed soils is influenced by longer photoperiods. In the alpine species tested and those arctic ones commonly found on deeply thawed soils, the seeds of which germinate equally well in light and darkness, germination is enhanced by shorter photoperiods. The data presented here are insufficient to support any conclusions as to the causes of this division into habitat groups of species according to germination differences.

Soil-surface temperatures at Umiat ranged from $31^{\circ}$ to $92^{\circ} \mathrm{F}$. with monthly means between $45^{\circ}$ and $54^{\circ} \mathrm{F}$. in 1953 . Surface and soil temperatures were somewhat higher on steep slopes and river-gravel areas. Alpine soil-surface temperatures ranged from $33^{\circ}$ to $97^{\circ} \mathrm{F}$. in 1954 and 1955 , with monthly means between $46^{\circ}$ and $62^{\circ} \mathrm{F}$. (Bliss, 1956). The tundra soils were thus quite favourable for germination in terms of temperature during the growing season, for Sørensen (1941) has pointed out that many arctic seeds germinated in Greenland when temperatures were above the freezing point for only about one half of each 24-hour period.

Seeds of Salix brachycarpa remained viable in storage for a longer period than those of S. planifolia var. monica. Since seeds of the former species ripen in late August, whereas those of the latter ripen by the end of July, it would appear that seeds of $S$. brachycarpa are better able to overwinter and germinate in the spring. Söyrinki (1938-9) believed that 
some species of Lapland willows were capable of germination after overwintering. Germination tests and field observations showed that seeds of Salix planifolia var. monica germinated immediately after dispersal and that their viability decreased rapidly. Seedling establishment in this species thus usually occurs in the same season as seed production.

Field observations tend to confirm the results of the germination tests on the arctic species. Seedlings were quite common on the deeply thawed soils, especially on the sands and silts of flood plains. Dormancy was broken in seed from all species occupying these habitats, except the willows. In contrast, many of the species that typically grow in the wet tundra soils that thaw only shallowly, appear to reproduce mainly by vegetative means, for seedlings were difficult to find. These observations corroborate the germination tests in which dormancy was broken in the seeds of only 13 of the 25 species that commonly grow in the wet tundra soils. In the alpine tundra seedlings of many species were found; this indicates that reproduction through seed occurs in addition to vegetative propagation. Seeds of 80.7 per cent of the species germinated.

Numerous species that flowered abundantly and set considerable amounts of seed at Umiat flowered much less intensively and set little, if any, seed on the Coastal Plain in 1953 (Bliss, 1956). The Coastal Plain is less favourable for plant development than the Umiat area in terms of microenvironments. Similar observations were made in the alpine tundra, where plant height, flowering, and seed production, were reduced in those species growing on an exposed ridge as opposed to the same species growing in more favourable microenvironments on both north- and south-facing slopes. Thus local variations in flowering and fruiting as the result of habitat extremes may be as great as over large geographical areas.

These data concerning apparent habitat preferences as well as germination percentages in light and dark chambers should not be interpreted as being characteristic of these species in other tundra regions. Some of the species that flower and fruit abundantly in low and mid arctic regions seldom flower or set fruit in the High Arctic. Of necessity vegetative propagation is most important there. Habitat preferences of some species may also change from northern Alaska to northern Greenland and Ellesmere Island.

\section{Summary}

Germination tests on seeds collected in the arctic tundra of northern Alaska and the alpine tundra of southeastern Wyoming indicate that viable seed is produced by many species in each region. Seeds of a greater proportion of alpine than of arctic species germinated, although high percentages of germination were found in individual species from both tundras. The results of the germination tests carried out in light and darkness on the various arctic plants correlate quite well with differences in their general habitats. Most species that are usually found on deeply thawed 
soils (flood plains, steep slopes, and dry ridges) produce seeds, which germinate equally well in the light and in the dark. Viable seeds were found in 91 per cent of these species. The seeds of nearly all the species most frequently found in the wet tundra soils that thaw only shallowly had significantly lower germination percentages in the dark. Even in the light only 48 per cent of the seeds of these species germinated, and 76 per cent did not germinate at all in the dark. There is no indication of habitat segregation of the alpine plants based on germination in the light and the dark, although reduced rates of germination in the dark were recorded in some species.

It is suggested that the arctic and alpine species that produce seeds that germinate equally well in the light and the dark are species the seeds of which are subject to being buried, or are species the seeds of which are not light sensitive. The species in which germination is significantly reduced in the dark may be light sensitive. Length of photoperiod may also play a role in these differences in germination.

Seeds of the alpine willow (Salix brachycarpa) remain viable over winter and in nature probably germinate in the spring. This species does not mature its seeds until late August. Salix planifolia var. monica, however, matures its seeds in July and the seeds can germinate immediately. Germination tests indicated that viability is seldom, if ever, retained over winter in this species. Seedling establishment probably occurs during the same season in which the seeds are produced.

These results corroborate field observations that seedlings of arctic species are more abundant for those plants that grow on deeply thawed soils. Vegetative propagation is the most important means of reproduction in many of the species restricted to shallowly thawed soils in the upland tundra. The germination data for alpine species substantiate the field observations that seedlings are quite common, although vegetative propagation is also of great importance.

Generalizations based on this study should only be made regarding the germination pattern and habitat preferences of these species in the areas discussed, because the species may vary considerably elsewhere throughout the tundra regions.

\section{References}

Bliss, L. C. 1956. A comparison of plant development in microenvironments of arctic and alpine tundras. Ecol. Monogr. 26:303-37.

Bliss, L. C. and J. E. Cantlon. 1957. Succession on river alluvium in northern Alaska. Am. Midl. Nat. 58:452-69.

Böcher, T. W. 1949. Climate, soil, and lakes in continental West Greenland in relation to plant life. Medd. om Grønl. 147(2):1-63.

Harrington, H. D. 1954. Manual of the plants of Colorado. Denver: Sage Books Co. $666 \mathrm{pp}$.

Hoch, A. E., E. W. Hertel, W. O. Oakes, and H. H. Whitwell. 1941. Root habits of certain plants of the foothills and alpine belts of Rocky Mountain National Park. Ecol. Monogr. 11:327-45. 
Holm, T. H. 1922. Contributions to the morphology, synonymy, and geographical distribution of arctic plants. Rept. Can. Arc. Exp. 1913-18, Vol. 5, Pt. B, 139 pp.

Holttum, R. E. 1922. The vegetation of West Greenland. J. Ecol. 10:87-108.

Hultén, E. 1937. Outline of the history of arctic and boreal biota during the Quarternary period. Stockholm: Bokforlags Aktiebolaget Thule, $168 \mathrm{pp}$.

Vol. 37-46, $1902 \mathrm{pp}$.

1941-50. Flora of Alaska and Yukon. Lunds Univ. Årsskrift N.F.,

Nichols, G. E. 1934. The influence of exposure to winter temperatures upon seed germination in various native American plants. Ecol. 15:364-73.

Pelton, J. 1956. A study of seed dormancy in eighteen species of high altitude Colorado plants. Butler Univ. Bot. Stud. 13:74-84.

Polunin, N. 1951. The real Arctic: suggestions for its delimination, sub-division and characterization. J. Ecol. 39:308-15.

Porsild, A. E. 1920. Sur les poids et les dimensions des grains arctiques. Revue Générale de Botanique. 32:97-120.

1951. Plant life in the Arctic. Can. Geog. J. 42:120-45.

Porsild, M. P. 1920. Flora of Disko Island and West Greenland, from $66^{\circ}-71^{\circ} \mathrm{N}$. latitude. With remarks on phytogeography, ecology, flowering, fructification, and hibernation. Medd. om Grønl. 58 (1): 1-156.

Sørensen, T. 1941. Temperature relations and phenology of the northeast Greenland flowering plants. Medd. om Grønl. 125 (9): 1-305.

Söyrinki, N. 1938-39. Studien über die generative und vegetative Vermehrung der Samenpflanzen in der alpinen Vegetation Petsamo-Lapplands I und II. Ann. Soc. Zool.-Bot. Fenn. Vanamo. 11:1-323 and 14:1-405.

Stoeckeler, E. G. 1949. Identification and evolution of Alaskan vegetation from air photos with reference to soil, moisture, and permafrost conditions. U. S. Army Corps. Eng. St. Paul, Minn. 103 pp.

Wager, H. G. 1938. Growth and survival of plants in the Arctic. J. Ecol. 26: 390-410. 